DOI https://doi.org/10.36059/978-966-397-117-9/336-357

\title{
LEVEL OF LEGAL CONSCIOUSNESS OF THE PERSONALITY AS A GUARANTEE OF HUMAN RIGHTS PROTECTION
}

\section{Shvachka V. Yu.}

\section{INTRODUCTION}

The development of democratic relations, the formation of public society, law-governed state in Ukraine require the formation of socioactive personality with a high level of legal consciousness and legal culture as well as recognition the law as the main regulator of public relations.

Law as a means of both social regulation of public relations and a component of the subject of the state and law theory has been the object of research of national and foreign law theorists not only once.

Law is a meaningful value for a modern society as well as every person: its influence on the life of the state, society as a whole, every citizen is rather deep and complex; that is why it can not be explained in a simple and one-sided way.

Most of the authors support the normative school of legal thinking, according to which law is considered as a normative and voluntary regulator of public relations, as an internal mutually agreed system of formally defined norms established or authorized by the state, provided by coercive force of the state ${ }^{1}$.

Law in society is not merely a "phenomenon in itself", but as an external phenomenon, a powerful regulatory means that requires a person to act in accordance with the requirements of law $^{2}$. In this meaning, law is a social regulator, a certain degree of freedom, based on the achievements of human civilization and culture, serves as a criterion of public

\footnotetext{
${ }^{1}$ Теорія держави і права. Академічний курс: Підручник для студентів юридичних спеціальностей вищих навчальних закладів / МОНУ; За ред. О.В.Зайчука, Н.М. Оніщенко; Авт.: Зайчук О.В., Заєць А.П., Копиленко О.Л., Оніщенко Н.М. та ін. - Київ: Юрінком Інтер, 2008. - С. 272.

${ }^{2}$ Теорія держави і права. Академічний курс: Підручник для студентів юридичних спеціальностей вищих навчальних закладів / МОНУ; За ред. О.В.Зайчука, Н.М. Оніщенко; Авт.: Зайчук О.В., Заєць А.П., Копиленко О.Л., Оніщенко Н.М. та ін. - Київ: Юрінком Інтер, 2008. - С. 240.
} 
usefulness definition (lawfulness) or danger (unlawfulness) of human behavior and their associations ${ }^{3}$.

Today, the Ukrainian legal science expands the philosophical understanding of law (V. Selivanov, N. Videnko), according to which law is the set of ethical social values such as justice, order, morality, honesty and others based on the idea of social equality ${ }^{4}$.

The transition from a narrow normative understanding of law as the law of authorities to a liberal understanding of law as a measure of freedom, establishing the humanistic value content of law, enriches our understanding of the law and the legal system, promotes the creation of respect for law and lawful conduct, value orientations of society, state and people ${ }^{5}$.

Thus, universal human values prevail in the basis of norms of modern law and at the same time, the law is the means by which they are exercised.

In addition, the ability, skills and readiness of a person to uphold their rights and to recognize similar rights for other people are becoming more and more important.

Respect for law as well as its recognition as a main social regulator of public relations is an indicator of a high level of person's legal consciousness, which in turn is a positive result of its legal socialization. A person with a high level of legal consciousness, on the one hand, recognizes their responsibilities to society and on the other hand, knows their rights and does not allow their violation.

Thus, under the legal consciousness one should understand the proper qualitative level of knowledge of law, understanding of its necessity and participation in the internal motivation of acts and actions of the person, achieved in the process of successful legal socialization of the personality.

\section{Legal Consciousness of Personality as a Result of Their Legal Socialization}

The issue of the concept, content and essence of legal consciousness sparked interest among national and foreign scholars. The essence and

\footnotetext{
${ }^{3}$ С.Л. Лисенков.Ззагальна теорія держави і права. Навчальний посібник. - К.: «Юрисконсульт», 2006 . C. 123.

${ }^{4}$ Селиванов В., Діденко Н. Правова природа регулювання суспільних відносин // Право України. 2000. - № 10. - С. 16.

${ }^{5}$ Правові системи сучасності. Глобалізація. Демократизм. Розвиток / В.С. Журавський, О.В. Зайчук, О.Л. Копиленко, Н.М. Оніщенко; За заг. ред. В.С. Журавського. - К.: Хрінком Інтер, 2003. - С. 63.
} 
significance of legal consciousness was highlighted in the works of wellknown pre-revolutionary scholars, including I.O. Ilyin, P.I. Novgrodtsev, B.O. Kistyakovsky. The issues of legal consciousness were considered by the Ukrainian well-known scholars in the works of V.D. Babkin, M.I. Kozyubra, V.V. Kopeichikov, E.V. Nazarenko, N.M. Onishchenko, N.M. Parkhomenko, O.F. Skakun, P.M. Rabinovich, M.V. Zwick et al.

There is a range of definitions of the legal consciousness concept in philosophical and legal literature.

On the one hand, according to N.M. Parkhomenko, a set of ideas, representations, feelings, reflecting the attitude of society to law, its structure, the mechanism of the legal regulation of public relations is understood under the legal consciousness. On the other hand, legal consciousness can be seen as a way of law influence through the consciousness of some individuals on consolidation of the skills of their legal positive behavior ${ }^{6}$.

As a rule, legal consciousness is defined as a system of legal representations, feelings, beliefs, emotions, ideas, views, assessments and other manifestations, expressing the subjective attitude of the personality, social group, society as a whole to both a person, current law, existing legal practice, legal status of a person, other legal phenomena, and to the desired law and other desirable legal changes. The same definition is given by the national legal scholar I. Golosnichenko, who considers legal consciousness as a set of representations, views, beliefs, assessments, mood and emotions concerning the attitude of people to the law and statelegal phenomena ${ }^{7}$.

The significance of the above definition lies not only in the full scope of the system elements of legal reality reflection, but also in the dynamic approach to determining the issue of legal consciousness. Legal consciousness is not only reflected in the legal categories, concepts, theories, feelings, views of people about legal reality, but also directs the subject of the law to certain changes in the legal environment, predicts and constructs them ${ }^{8}$.

\footnotetext{
${ }^{6}$ Теорія держави і права. Академічний курс: Підручник для студентів юридичних спеціальностей вищих навчальних закладів / МОНУ; За ред. О.В.Зайчука, Н.М. Оніщенко; Авт.: Зайчук О.В., Заєць А.П., Копиленко О.Л., Оніщенко Н.М. та ін. - Київ: Юрінком Інтер, 2008. - С. 554.

7 Голосніченко І. Правосвідомість і правова культура у розбудові Української держави // Право України, 2005, № 4. - С. 24.

8 Загальна теорія держави і права: Навчальний посібник / МОУ. НПУ ім. М.П. Драгоманова. А.М. Колодій, В.В. Копейчиков та інші. - Стереотипне видання. - Київ: Юрінком Інтер, 1999. - С. 137.
} 
N.M. Onischenko gives the same definition of legal consciousness, in her opinion; legal consciousness reflects the legal reality in the form of legal knowledge and value attitude to the law and practice of its implementation, legal orientations and value orientations governing the behavior (activity) of people in legally significant situations. It is a source of legal activity and an internal regulator of legally significant behavior or a mechanism for its implementation ${ }^{9}$. As O.F. Skakun rightly points out, the key point of legal consciousness is the human awareness of the values of natural law, human rights and freedoms, and the assessment of current law in terms of its conformity with universal human values found in international human rights documents. Legal consciousness not only expresses the attitude of the individual to legal reality, but also directs it to certain changes in the legal environment, predicts and constructs them ${ }^{10}$.

The purpose, place and role of legal consciousness in the legal field of public life are determined by the fact that any legal reality is impossible without awareness of its subjects of their actions. This applies to all types of law-making, law enforcement and law protection activities ${ }^{11}$.

The meaningful definition of legal consciousness is included in the works by L.I. Spiridonov. According to the scholar, the concept of legal consciousness in modern science means one of the types of public consciousness, reflecting the legal reality. Under the legal reality here is understood not only the law and the legal act, but also the offences of all kinds, offenders themselves, and normative acts and acts of lawenforcement activities, as well as the activity itself ${ }^{12}$.

Legal consciousness as a component of a new legal culture of a person, under modern conditions of Ukrainian society development, is characterized, first of all, by new legal thinking, considerable practical interest in law and legal institutions, changing the attitude to law as a mechanism for the non-conflict realization of their interests, the law has acquired specific features and values for everyone.

At the same time, the current socio-cultural situation in Ukraine is such that these processes are not supported by a legal tradition, both in public and in individual legal consciousness; law is a doubtful value. With

\footnotetext{
${ }^{9}$ ОніщенкоН.М. Правова система: проблеми теорії: Монографія. - К.: Ін-т держави і права ім. В.М. Корецького НАН України, 2002. - С. 68.

${ }^{10}$ Скакун О.Ф. Теорія держави і права. - К.: Алерта, 2013. - 524 с.

${ }^{11}$ Лисенков С.Л. Загальна теорія держави і права. - К.: «Юрисконсульт», 2006. - С. 180.

12 Спиридонов Л.И. Теория государства и права.Учебник. - м.: ПБОЮЛ М.А.Захаров, 2001. С. 122.
} 
the renewal of legislation and accumulation of relevant law enforcement practices, the gap between the new democratic legislation and the low level of legal consciousness is getting increasingly obvious ${ }^{13}$.

Considering the legal consciousness as a means by which the interaction of a person with law, legal act is carried out, and through them - with the economic, political situations, environment, living conditions, life, etc., V.V. Golovchenko notes that its formation is carried out not only (and, perhaps, not so much) by normative-legal acts, not so much under the influence of purely legal practice, but due to the action of new trends in the field of economy, politics, and morality. It is these tendencies that are the driving forces stimulating a person to a new legal thinking ${ }^{14}$. In this case, the subjective-mental environment, reflecting the attitude of people to the law, is essential, and the quintessence of legal consciousness is the human awareness of law value and, at the same time, the belief in a current positive law, of how much it meets the requirements of mind and justice, legal values, and ideals ${ }^{15}$.

Today, the formation of legal consciousness in Ukraine is taking place in the acute struggle of new legal thinking with the old one, which creates a complex ideological and political-legal problem, requiring new approaches in the formation of goals, tasks of legal socialization of the personality and a search for new means and ways of its implementation. The formation of legal consciousness as a positive result of legal socialization of personality and overcoming of prevailing legal nihilism should become one of the priority directions of state policy.

Legal consciousness as a form of social consciousness obeys its general laws of formation and functioning. At the same time, the legal consciousness has its own specificity, which distinguishes it from other forms of consciousness and manifests itself in the subject of reflection, as well as in its special concepts and categories. They include the categories of legal rights and obligations, "lawfulness", "unlawfulness", "legal relations", "legal capacity", as well as "legitimacy", etc. Based on these categories, legal consciousness reflects an assessment of behavior of law

\footnotetext{
${ }^{13}$ Вступ до теорії правових систем / НАН України; Інститут держави і права ім. В.М. Корецького / Олег Володимирович Зайчук (заг.ред.), Наталія Миколаївна Оніщенко (заг.ред.). - К. : Юридична думка, 2006. - С. 146.

14 Головченко В.В. Деякі тенденції розвитку масової правосвідомості // Правова держава, 1994. Вип. 5. - С. 76.

15 Державотворення і право творення в Україні: досвід, проблеми, перспективи / За ред. Ю.С. Шемшученка: Монографія. - К.: Ін-т держави і права ім.. В.М. Корецького, 2001. - С. 329.
} 
subjects as lawful or unlawful ${ }^{16}$. It is the establishment and strengthening of the legitimacy that is one of the manifestations of legal consciousness. The subject of its reflection is the law and legal regulation as a whole, as well as public relations, regulated by law or those that require legal regulation.

According to N.M. Onishchenko, the specificity of legal consciousness is expressed in the prediction of public-obligatory behavior, justifying the need to establish legal rights and obligations of participants in public relations ${ }^{17}$.

Legal consciousness is a complex structured institution. Its structure manifests itself in the form of certain interconnected elements and institutions. The distinction of structural elements in the legal consciousness contributes facilitates the clarification of its place and role in society.

In scientific literature the structure of legal consciousness (as any type of public consciousness) is studied in the various aspects.

Using different approaches to studying the structure of legal consciousness, scientists rather often give preference to one or another element. Some authors focus on its cognitive and evaluative aspects and consider the volitional aspect of legal consciousness as a consequence of these two parts. In the concept of other authors, cognitive and evaluation features go to the background, and the focus is on the volitional side, the active influence of legal consciousness on the law. The factors mentioned are really the elements, components of legal consciousness. It can be mentioned that these factors or elements of legal consciousness include certain independence in relation to each other. At the same time, their boundaries are very conditional.

In fact, it is difficult to draw a line between the cognitive and evaluative sides of legal consciousness. Passive cognition is not possible by itself, since, as a rule, it is associated with the evaluation of any particular fact or behavior. Although the relation between the cognitive, evaluative and volitional sides of cognition is variable and relative, they can still be distinguished, guided by the nature of their relations with the

\footnotetext{
16 . Соціологія права: Підручник для студентів юрид. Спец. Вищих навчальних закладів / За ред. Н.П. Осипової. - К.: Концерн „Видавничий дім „Ін Юре”, 2003. - с.157.

17 Горбунова Л.М., Оніщенко Н.М., Копієвська О.Р. Методика правової освіти. - К.: Атака-Н, 2005. C. 5.
} 
legal system, and then with the law in an even more general form ${ }^{18}$. We will discuss each of them in more detail later. The structure of legal consciousness can be considered in several aspects, in particular, in axiological (evaluative) and structural-functional.

The axiological aspect of determining the structure of legal consciousness proceeds from the fact that the value of law in satisfying the needs of the subject is the subject of a peculiar cognitive (evaluative) activity, the results of which are reflected and recorded in the minds of the personality in the form of evaluations. Evaluation in the general form is an intellectual (rational) and sensory (emotional) reaction of the subject to the determination of the role and significance of a particular object, both for themselves, and for others.

In the axiological aspect, legal consciousness is a reflection of the cognitive (evaluative) activity of the subject, the result of which is the consolidation of certain legal knowledge in person's mind, as well as assessment of law and various legal phenomena. In this aspect, in the structure of legal consciousness, as a rule, two elements are distinguished: legal ideology and legal psychology ${ }^{19}$.

Legal ideology is a system of legal ideas, theories, concepts, norms, views, based on certain scientific and political knowledge and representations $^{20}$. Legal ideology is a rational element of legal consciousness, formed as a result of scientific, theoretical reflection of legal reality, based on generalization and development of the most famous and significant state-legal theories of the past and the present, the study of basic patterns of attitudes, development and functioning of state and law, their role in the life of society.

Thus, the formation of legal ideology is a goal-oriented process of theoretical understanding of interests, goals and tasks of society, state, personality, the leading element of which is intelligence.

Legal ideology substantiates and evaluates the established or predicted legal relations, the role of law, legitimacy and law order. In the

\footnotetext{
18 Имбре Само.Основы теории права. Перевод с венгерского под.ред. В.А.Туманова. М., 1974, C. 210-211.

19 Теорія держави і права. Академічний курс: Підручник для студентів юридичних спеціальностей вищих навчальних закладів / МОНУ; За ред. О.В.Зайчука, Н.М. Оніщенко; Авт.: Зайчук О.В., Заєць А.П., Копиленко О.Л., Оніщенко Н.М. та ін. - Київ: Юрінком Інтер, 2008. - С. 557.

Лисенков С.Л. Загальна теорія держави і права. - К.: «Юрисконсульт», 2006. - С. 181.

Правові системи сучвсності. глобалізація. демократія. розвиток.

${ }^{20}$ Юридична енциклопедія: В 6 т./ Редкол.: Ю.С. Шемшученко (голова редкол.) та ін. - К.: «Укр. енцикл.», 2001. - Т. 2. - С. 658.
} 
development of legal ideology, scientists, practitioners, politicians and other specialists take part, taking into account the specific historical living conditions of a society, its economic conditions, demographic processes, the level of public consciousness, the mood and interests of different social groups, the dynamics of offences and other factors. In essence, it is about the formation of legal consciousness at the theoretical level, which involves professionals.

Modern legal ideology in the opinion of S.L. Lysenkov includes, in particular: the concept of division of powers; the recognition of priority of universal human values over the interests of certain segments of society and, accordingly, the domination of generally accepted norms of international law over the norms of national law; the theories of lawgoverned state and civil society; the principles of democracy, humanism, non-alienation of natural human rights, etc ${ }^{21}$.

The second element of legal consciousness is an emotional-structural element that is called legal psychology.

Legal psychology covers a set of legal feelings, values relations, moods, desires and experiences that are typical of the personality, society as a whole or a specific social group ${ }^{22}$.

Legal psychology in contrast to the rational formation of legal ideology is formed spontaneously based on empirical direct reflection of legal behavior of legal relation subjects in the form of public opinion, experiences, feelings, emotions, assessments, etc ${ }^{23}$.

In the opinion of O.F. Skakun, it is not a conscious or not fully realized attitude towards the law, legal phenomena, which is a legal consciousness that comes from everyday practice in the process of meeting with specific legal situations, and therefore is formed in the most part spontaneously, sporadically, unsystematically, that is, legal psychology is not comprehended theoretically, not ordered logically ${ }^{24}$.

The emergence and existence of legal psychology is associated, first of all, with the natural inclusion of emotions in the human consciousness structure and with a direct sensory reflection of the legal environment,

\footnotetext{
21 Лисенков С.Л. Загальна теорія держави і права. - К.: «Юрисконсульт», 2006. - с. 181.

22 Правові системи сучвсності. Глобалізація. Демократизм. Розвиток / В.С. Журавський, О.В. Зайчук, О.Л. Копиленко, Н.М. Оніщенко; За заг. ред. В.С. Журавського. - К.: Юрінком Інтер, 2003. - C. 58

23 Загальна теорія держави і права: Навчальний посібник / МОУ. НПУ ім. М.П. Драгоманова. А.М. Колодій, В.В. Копейчиков та інші. - Стереотипне видання. - Київ: Юрінком Інтер, 1999. - С. 138.

${ }^{24}$ Скакун О.Ф. Теорія держави і права. - К.: Алерта, 2013. - С. 462.
} 
emotional response to external legal phenomena relating to them. Emotional coloring, whether positive or negative, substantially affects the nature and direction of person's behavior, including in the field of legal relations. That is why legal psychology is considered as a reflection of direct experience of people's participation in legal relations, practical participation in the legal field of society life. Legal psychology is a practical legal consciousness, based on legal feelings, and experiences, it is associated with elementary knowledge of legal facts, phenomena, their evaluation, manifested both in legal feelings, and in legal skills and habits.

In this regard, the national legal scholar S. L. Lysenkov distinguishes the complex structure of legal psychology separating the following elements inside it: stable (legal customs, traditions, habits) and dynamic (mood, feelings, experiences); cognitive (legal empirical knowledge, beliefs, views) and emotional (legal emotions, feelings, mood); regulatory (legal habits, traditions, customs) ${ }^{25}$.

Legal ideology and legal psychology as elements of legal consciousness are closely interrelated. Legal ideology enriches legal psychology with value-normative orientations, and legal psychology is the only source for the formation of legal norms, since, unlike legal ideology, it is more mobile: it responds quickly to changes taking place in legal practice, reflected in mood, feelings, and views, which, in turn, directly affect the human perception of legal changes ${ }^{26}$.

Taking into account, that in the context of this study a high level of legal consciousness is considered as a positive result of legal socialization of the personality in the process of formation of their active socio-legal position deserves the attention of O.F. Skakun's opinion about the distinguishing of the third element in the structure of legal consciousness, namely, legal behavior. Legal behavior, as a volitional side of legal consciousness, represents the process of transferring legal norms into real legal behavior. Behavioral element of legal consciousness synthesizes rational and emotional aspects. The implementation of psychological and ideological elements takes place through $\mathrm{it}^{27}$.

\footnotetext{
25 Лисенков С.Л. Загальна теорія держави і права. - К.: «Юрисконсульт», 2006. - С. 182.

${ }^{26}$ Теорія держави і права. Академічний курс: Підручник для студентів юридичних спеціальностей вищих навчальних закладів / МОНУ; За ред. О.В.Зайчука, Н.М. Оніщенко; Авт.: Зайчук О.В., Заєць А.П., Копиленко О.Л., Оніщенко Н.М. та ін. - Київ: Юрінком Інтер, 2008. - С. 558.

${ }^{27}$ Скакун О.Ф. Теорія держави і права. - К.: Алерта, 2013. - С. 464.
} 
Thus, the level of legal consciousness precisely depends on its behavioral element, which can manifest itself in lawful behavior, legal activity, offence, etc.

In the process of research of legal consciousness and its structure in the context of legal socialization of the personality, the structuralfunctional aspect of its consideration deserves special attention.

Growing up, a person experiences some influence of the environment and special legal education, as well as increasingly enters into the practice of social, including legal communication, becomes conscious participant in various relations, and, consequently, the requirements for their legal socialization are increasing, and new tasks are arising, which, in turn, are related to the definition of structure, functions and the process of formation and development of their legal consciousness.

In the process of legal socialization the idea of law and its significance in everyday life are formed in person's mind. This occurs through the influence of various life circumstances on a person, including the environment and legal-educational influence; and as a result a person not only aware of them, but also there are relevant emotions in person's consciousness as well as own attitude towards them.

Thus, patterns of behavior, which at first are external to the subject, are gradually becoming its internal, subjective, internalized actions. And only then they are supported and ensured, first of all, by the internal conviction and the will of the personality.

This way, the level of legal consciousness, which is the result of legal socialization, influences the person's attitude to law, its role and meaning in person's everyday life. The higher the level of legal consciousness, the more stable the legal convictions of the personality, the more they regulate their behavior in accordance with the goals and tasks expressed in law.

It is the structural-functional approach in the study of legal consciousness that makes it possible to distinguish three groups of its functions: cognitive, evaluation, regulatory.

Cognitive functions of legal consciousness are provided by knowledge of law. The evaluation functions correspond to the system of views on legal issues (attitude to law). The action of regulatory functions consists in legal orientations, guidelines and skills of legal behavior ${ }^{28}$.

\footnotetext{
${ }^{28}$ Социальные отклонения. Введение в общую теорию. - М.: Юрид. лит., 1984. - С. 182.
} 
Some authors define the main functional elements of legal consciousness in accordance with the functions defined above: ${ }^{29}$ cognitive (informational), evaluative and regulatory (volitional).

Cognitive activity corresponds to a certain amount of legal knowledge (ideas, categories, views, etc.) that is the result of intellectual activity and is expressed in the concept of "legal training".

Cognizing the legal reality, a person does not remain indifferent to the knowledge gained. Knowledge always causes a person's attitude towards them, that is, they are evaluated.

The evaluative function determines a person's emotional attitude to different legal phenomena on the basis of received legal knowledge, own experience and legal practice. As a result of evaluation activity of the objects of legal cognition and legal reality, emotional ideas, so-called "evaluative considerations" are formed in the personality. At the same time, the presence of views and considerations in the personality as a result of cognitive and evaluation activities in relation to the law, various legal phenomena and practices of its application, does not indicate the readiness of the person to implement them in practice. The decisive role in ensuring the lawful behavior of a person through the practical implementation of value orientations is given to intellectual-emotionalvolitional institutions, the so-called legal guidelines, formed with the participation of the person's will.

Legal guideline is the readiness, the personality's inclination to perceive and evaluate any legal object in a certain way and act in relation to it in accordance with this evaluation ${ }^{30}$. It is a specific program of behavior under the certain conditions, which is formed from all the relevant subjects of legal (lawful and unlawful) knowledge, evaluations, thoughts, mood, habits, skills, expectations, attitudes to anyone or anything that turn into interests and aspirations.

Dominant legal guidelines determine the life attitude of the personality and characterize the content of their value-legal orientations. The set of such guidelines forms the value-legal orientation of the personality. Accordingly, legal orientation is a set of legal guidelines of a

\footnotetext{
${ }^{29}$ Правовое воспитание молодежи / Н.И. Козюбра, В.В. Оксамытный, П.М. Рабинович и др. Отв. ред. Н.И. Козюбра. - К.: Наукова думка, 1985. - С. 16.; Соціологія права: Підручник для студентів юрид. Спец. Вищих навчальних закладів / За ред. Н.П. Осипової. - К.: Концерн «Видавничий дім «Ін Юре»0, 2003. - С. 304;. Скакун О.Ф. Теорія держави і права. - К.: Алерта, 2013. - С. 467.

${ }^{30}$ Правовое воспитание молодежи / Н.И. Козюбра, В.В. Оксамытный, П.М. Рабинович и др. Отв. ред. Н.И. Козюбра. - К.: Наукова думка, 1985. - С.16.
} 
personality or community (group, association) that directly forms an internal plan, a program of activities in legally significant situations. ${ }^{31}$

It is the regulatory function of legal consciousness that is implemented through legal systems and value-legal orientations, synthesizing all other sources of legal activity. The result of such regulation is a behavioral reaction in the form of lawful or unlawful behavior $^{32}$.

\section{Functional structure of legal consciousness}

\begin{tabular}{|c|c|c|c|}
\hline $\begin{array}{c}\text { Basic functions } \\
\text { of legal } \\
\text { consciousness }\end{array}$ & $\begin{array}{c}\text { Mental } \\
\text { components }\end{array}$ & $\begin{array}{c}\text { Function } \\
\text { results }\end{array}$ & $\begin{array}{c}\text { Empirical } \\
\text { indexes }\end{array}$ \\
\hline Cognitive & Intellectual & Legal training & $\begin{array}{c}\text { Law knowledge and } \\
\text { skills of using it }\end{array}$ \\
\hline Evaluative & $\begin{array}{c}\text { Intellectual- } \\
\text { emotional }\end{array}$ & $\begin{array}{c}\text { Value attitude to } \\
\text { law and its } \\
\text { implementation } \\
\text { practice }\end{array}$ & $\begin{array}{c}\text { evaluation } \\
\text { consideration } \\
\text { (views) }\end{array}$ \\
\hline Regulatory & $\begin{array}{c}\text { Intellectual- } \\
\text { emotional-volitional }\end{array}$ & $\begin{array}{c}\text { Legal guidelines } \\
\text { and orientations }\end{array}$ & $\begin{array}{c}\text { Behavioral attitude } \\
\text { (decision) }\end{array}$ \\
\hline
\end{tabular}

Taking into account the above mentioned, in the author's opinion, the structure of legal consciousness given by national scholars, namely V. V. Kopeychykov and O. F. Skakun is the most successful, who, using the structural-functional approach, distinguish its three components: legal knowledge, legal evaluations and legal guidelines ${ }^{33}$. Each element of the structure of legal consciousness corresponds to its basic functions, which, in turn, are equally important for the process of legal socialization of the personality and are implemented step-by-step one after another.

Therefore, it is precisely in the process of implementing cognitive functions that a certain system of legal knowledge is formed in the person's mind, which is the primary element of its structure. Later on, the evaluation of the acquired legal knowledge is carried out, a certain

\footnotetext{
31 Соціологія права: Підручник для студентів юрид. Спец. Вищих навчальних закладів / За ред. Н.П. Осипової. - К.: Концерн «Видавничий дім «Ін Юре», 2003. - С. 165).

${ }^{32}$ Каминская В.И, Ратинов А.Р. Правосознание как элемент правовой культуры//Правовая культура и вопросы правового воспитания. М., 1974. - С. 87.

33 Загальна теорія держави і права: Навчальний посібник / МОУ. НПУ ім. М.П. Драгоманова. А.М. Колодій, В.В. Копейчиков та інші. - Стереотипне видання. - Київ: Юрінком Інтер, 1999. - С. 139.

Скакун О.Ф. Теорія держави і права. - К.: Алерта, 2013. - С. 467.
} 
attitude of the person is formed to it, a selective inclusion of it in their inner world, knowledge becomes person's own convictions, the so-called "standards of behavior", leading to the emergence of the second element of legal consciousness such as legal evaluations.

At the same time, legal consciousness is not a set of knowledge about law or reflection of a person's fixed attitude to it, because it not only reflects the legal reality, but also changes it through active legal behavior of the subject. This, in turn, explains the distinguishing of the third element of the legal consciousness structure, namely, legal guidelines, which are the result of its regulatory function. Regulatory function of legal consciousness is realized through the will of the person, their psychological peculiarities and ensures active legal behavior of the personality in everyday life. It is the active legal behavior of the personality that is manifestation of a higher level of their legal consciousness, which should be the main goal of legal socialization of the personality.

Diverse social communities, individuals and society as a whole are real bearers of legal consciousness, which makes it possible to divide it conditionally into three types: public, group (collective) and individual legal consciousness. The study of the nature of relations and interaction of which makes it possible to determine the place and role of legal consciousness in the process of legal socialization of the personality.

Only the answer to specific questions: whether the legal consciousness of society consists of the set of the legal consciousness of certain individuals; if public legal consciousness is the basis of formation of individual legal consciousness, will provide an opportunity to determine their real correlation.

In L.I. Spiridonov's opinion, if we consider society as a set of individuals, then, of course, individual legal consciousness precedes public legal consciousness.

At the same time, in the real world, when coming to life, the person automatically enters the society that is already formed with a certain level of public consciousness, including legal, and person has the only power to enter into a given society and occupy one of those places in it. From this point of view, public relations precede certain individuals, and therefore, the public consciousness precedes the consciousness of individuals, created before them and is perceived by them in the process of their 
socialization. This, in turn, confirms the fact that the legal consciousness, as well as the public consciousness as a whole, is an objective fact, a relatively independent social phenomenon which in general is not reduced to the amount of individual legal consciousnesses ${ }^{34}$.

This is due to the fact that in the individual legal consciousness the common features are combined that are inherent in the legal consciousness of a single epoch, together with the special features associated with the person's belonging to a particular social group, and the individual features, resulted from person's education and circumstances of personal life ${ }^{35}$.

Supporting the opinion that public legal consciousness is not a mathematical amount of individual legal consciousness, it should be noted at the same time that in our opinion, the legal consciousness of a particular individual also has a certain impact on the level and content of public legal consciousness in the process of his active legal activity.

So, indeed, public legal consciousness contains legal ideas, views, theories, which are common in the given society and reflect the typical features of its legal reality. It is objectified in the form of existing legislation, the system of law, law order, and the rule of law, legal culture and ideology. Consequently, the public legal consciousness can manifest itself in forms that do not exist and can not exist in the minds of certain people.

At the same time, all forms of manifestation of public legal consciousness in the course of their existence are influenced by the legal consciousness of certain individuals, which eventually undergoes certain changes. No doubt, the influence of social legal consciousness on the individual legal consciousness is much greater and is carried out through its concretization in the legal consciousness of certain social groups or groups directly surrounding the environment of the person. It gives grounds for asserting that individual legal consciousness is the result of the socialization of a certain person as well as person's assimilation of the group and public consciousness, mediated by the peculiarities of their life path. Collective forms of consciousness, plus personal experience - this is what creates the basis for perceiving the legal reality of each unique personality $^{36}$.

\footnotetext{
${ }^{34}$ Спиридонов Л.И. Теория государства и права. М., 2001. - С.122-123

${ }^{35}$ Покровский И.Ф. Формирование правосознания личности. Л., 1972. - С. 42.

${ }^{36}$ Спиридонов Л.И. Теория государства и права. М., 2001. - С. 127.
} 
Individual legal consciousness reflects the conditions of life of a particular person, the legal relations to which they are involved and the carrier of which this person is. Individual legal consciousness as a consciousness, not isolated from society, is always in one way or another covered by public consciousness and in this sense it can not be completely individual. Individual legal consciousness correlates with the collective as a part and a whole. Collective, public and individual legal consciousness interact with each other, but do not merge and do not coincide. Collective legal consciousness is a form of public consciousness and is not limited to a simple arithmetic amount of individual views, but also does not oppose the legal consciousness of individuals ${ }^{37}$.

Thus, one can speak of the deep dialectical unity of such subjects of legal consciousness as personality, group and society as a whole. Outside the public legal consciousness there is no and can not be the individual legal consciousness of the personality. At the same time, the high development of individual legal consciousness has an influence on the formation of public legal consciousness in general.

The reflection of the legal phenomena of reality by individual legal consciousness is rather specific. The subject's perception of the environment depends on many factors that can involve: the place of the person in the structure of social and interpersonal relationships, the extent of satisfaction of own interests, the quality of their life, and their available life experience, the possibility of realizing their creative potential, etc.

Determination of the place of reality legal phenomena in the system of person's values is carried out only in case of mandatory participation in the evaluation process of all these factors. And, first of all, the value of law for a personality is resulted from the value of the personality for law these phenomena are interrelated. Therefore, an inadequate low place of personality in the hierarchy of legal values reduces the "socializing effect" of legal means. The strictness of sanctions and intimidation does not solve the problem of socialization, because it does not contribute to the formation of a culture in individual legal consciousness, a respectful attitude to law and other subjects of social interaction. On the contrary, it is important to consolidate the legal system of the legal status of the personality and society as equal subjects.

\footnotetext{
${ }^{37}$ Методологические проблемы правосознания сотрудников внутренних дел. Л., 1986., С. 35-36.
} 
The path to this goal lies only through the construction of a lawgoverned state and a civil society, in which appropriate conditions will be created enabling personality to gain freedom of choice and the opportunity, using legal means, to resolve their own life-situations, as well as the proper place will be given to higher moral values of a person ${ }^{38}$.

\section{The Peculiarity of Legal Consciousness Formation in Ukraine}

Considering legal consciousness as the result of legal socialization, it is necessary to pay attention to the historical aspect of legal consciousness formation of the Ukrainian people, since the law of the past time does not disappear without a trace, but continues to exist under the new conditions as an inherited legal culture. The rich historical past of our country has had a decisive influence on the content of legal consciousness of the present.

The peculiarity of legal consciousness formation in Ukraine lies in the fact that due to historical circumstances it has been in the field of influence of two cultures: the Western and the Eastern ones, which overlapped each other ${ }^{39}$. For centuries, this or that part of the territory of Ukraine was influenced by different empires - Polish, Lithuanian, AustroHungarian and Russian, which left its imprint on the legal consciousness and legal culture of the Ukrainian people and resulted in its regional character.

As Y. Vaskovich notes, the law in the Western countries has a universal mandatory nature, equates everyone and everything, guarantees each person the inalienable rights and defines their duties. Law is the most significant social value there. All social groups and government structures are forced to exist and achieve their goal within the law.

In the Eastern countries, the hierarchy was based on social regulation for many years, that is, the law served the authorities. Here, power is perceived as a necessary need, an embodiment of will. Law-making is directed only from top to bottom, and the source of law is the power, that is beyond and above the law and is not subject to moral evaluation ${ }^{40}$.

\footnotetext{
${ }^{38}$ Хропанюк В.Н. Теорія государства и права. М., 1993. - С. 57; Оніщенко Н. М. Правова система: проблеми теорії / Інститут держави і права ім. В.М. Корецького НАН України. - К. : Ін-т держави і права ім. В.М. Корецького, 2002. - С. 69.

${ }^{39}$ Васькович Й. Правосвідомість та її вплив на менталітет українського народу. // Право України.1998. - № 6. - С. 108-111, С. 109.

40 Васькович Й. Правосвідомість та їі вплив на менталітет українського народу. // Право України.1998. - № 6 - C. 108-111, C. 109.
} 
The formation of Ukrainian statehood depended to a certain extent on the influence of Russian culture and legal thought. One of the common features of Russian pre-revolutionary legal thought was either a neglect attitude to law, or its complete defiance and idealization of the moral and religious factor. It was said not in vain a long time ago: people always ruled in Russ', but not laws ${ }^{41}$.

Unlike Western countries, where public relations was based on the recognition of the subjective rights and freedoms of a person as an achievement of human civilization for many centuries, public legal consciousness in Russia, including the legal consciousness of the vast majority of intellectuals, was never interested in the ideas of human rights, and the content of law was never associated with the categories of freedom, equality, and justice ${ }^{42}$. Law was not considered as an integral part of universal human culture, as a means of social regulation of public relations.

Ukraine's being in the Soviet Union with the command-and-control system of government also did not contribute to strengthening the authority of law, but, on the contrary, the law had a declarative nature and was used exclusively as a means of coercion in the hands of the ruling elite.

Thus, the Ukrainian people were taught to fear the law for hundreds of years, and not to respect and adhere to its demands, which gave rise to mass legal nihilism, which, in turn, was the evidence of a low level of legal culture and legal consciousness of people.

The proclamation of the independence of Ukraine, the change in the system of values of Ukrainian society is accompanied by a crisis of people's legal consciousness, which is a significant obstacle to the development of a law-governed state.

Well-known lawyer and philosopher P.I. Novgorodtsev, referring to the crisis of legal consciousness, linked it with changes in political and legal beliefs and attitudes, with the exaggeration of the role and importance of the idea of a law-governed state, with the positive laws moving behind the movement of history. As a consequence of this, in his

\footnotetext{
${ }^{41}$ Матузов Н.И. Правовой нигилизм и правовой идеализм, как две сторониы «одной медали» // Правоведение. 1994, № 2.- С. 8-16. - С. 10.

${ }^{42}$ Козюбра М.І. Творчий доробок М. Драгоманова. // Драгомаівський збірник. «Вільна спілка» та сучасний український конституціоналізм. За ред. Т.Г. Андрусика. Львів, 1996. - С. 90-96. - С. 92.
} 
opinion, conflicts arise constantly and inevitably between the old order and new progressive aspirations in a life ${ }^{43}$.

The crisis phenomena taking place in the economic, social life could not help influencing the level of legal consciousness of a person in Ukraine. It is under their influence that the younger generation is largely educated in an atmosphere of spiritual impoverishment, desolation, heartlessness, immorality, and disrespect for their parents, disbelief in the future. The uncritical transfer of doubtful values and moral norms of modern mass culture of the Western world to our own national background has greatly deformed consciousness, people's psychology ${ }^{44}$.

As a result of analysis of the person's legal consciousness level at the present stage of development of Ukrainian society, one can conclude that with declaration of Ukrainian independence, rejection of authoritarian methods of government, implementation of the constitutional idea of the supremacy of law, there has been a real possibility of developing Ukraine as a united integral law-governed state with the democratic principles of governance and formation of a proper level of legal consciousness and legal culture of citizens.

In order to achieve this goal, it is necessary, first of all, as I.O. Illin noted, to do everything "to bring the law to the people to consolidate the public legal consciousness, so that people understand, know and appreciate their laws, so they voluntarily adhere to their duties and prohibitions and loyally use their powers. Law must become a factor of life, a measure of real behavior, the power of the people's soul"45.

N.M. Parkhomenko defines the following ways of forming a legal consciousness: involving the wider population in law-making activity through the development of institutes of direct (immediate) and representative (referendums, public interviews) of democracy, aimed at understanding the content of legal acts, the reasons for their adoption and proper implementation; legal propaganda; correct implementation of legal norms by state authorities, state enterprises and institutions (ensuring this condition is a clear and effective activity of the employees of internal affairs bodies, prosecutors, raising the level of their legal culture); the

\footnotetext{
43 Новгородцев П.И. Введение в философию права. Кризиссовременного правосознания. - М., 1909. - С. 20, всего 265.

44 В. Головченко, А. Потьомкін Правові механізми формування правосвідомості судентів// Право України, 2006, № 4 - С. 100.

${ }^{45}$ Ильин И.А. О сущности правосознания. // Теория государства и права. Под. ред. д.ю.н., проф. В.А. Томсинова. - М.: Издательство «Зерцало», 2003.- 400 с. - С. 176.
} 
protection of constitutional rights and freedoms of a person and citizen by the authorized bodies of state power ${ }^{46}$.

\section{CONCLUSIONS}

The high level of legal consciousness of a person expressed in their active socio-legal attitude is achieved as a result of a successful combination of purposeful and spontaneous means of legal socialization, taking into account real life conditions, historical preconditions for their formation, social status of the person, level of general and legal culture of society, legal-educational work and person's individual capabilities.

The legal consciousness of a personality is a proper qualitative level of knowledge of law, recognition of its higher social value, understanding of its necessity and participation in the internal motivation of actions and acts of a person, achieved in the process of person's successful legal socialization.

The higher the level of legal consciousness, the more persistent the legal convictions of the personality, the more often they determine their behavior in accordance with the goals and tasks expressed in law. At the same time, the high level of development of legal consciousness of the personality has an influence on the formation of public legal consciousness in general. That, in turn, promotes the implementation and functioning of real human rights protection mechanisms.

\section{SUMMARY}

The issue of the concept, content and essence of legal consciousness is considered. It is determined that under the legal consciousness one should understand the proper qualitative level of law knowledge, understanding of its necessity and participation in the internal motivation of actions and acts of the person, achieved in the process of successful legal socialization of the personality.

Respect for law as well as its recognition as a main social regulator of public relations is an indicator of a high level of person's legal consciousness, which in turn is a positive result of their legal socialization. A person with a high level of legal consciousness, on the

\footnotetext{
${ }^{46}$ Теорія держави і права. Академічний курс: Підручник для студентів юридичних спеціальностей вищих навчальних закладів / МОНУ; За ред. О.В.Зайчука, Н.М. Оніщенко; Авт.: Зайчук О.В., Заєць А.П., Копиленко О.Л., Оніщенко Н.М. та ін. - Київ: Юрінком Інтер, 2008. - С. 555.
} 
one hand, recognizes their duties to society, and on the other hand, they know their rights and do not allow their violation.

Today, the formation of legal consciousness in Ukraine is taking place in the keen struggle of new legal thinking with the old one, creating a complex ideological and political-legal problem, which requires new approaches in forming the goals, tasks of legal socialization of the personality and the search for new means and ways of its implementation.

Different approaches to the study of the legal consciousness structure are analyzed and its main functions are determined.

The deep dialectical unity of such legal consciousness subjects as personality, group and society as a whole is studied. Outside the public legal consciousness there is no and it can not be the individual legal consciousness of the personality. At the same time, the high development of individual legal consciousness of the personality has an influence on the formation of public legal consciousness in general.

It is established that the higher the level of legal consciousness, the more persistent the legal convictions of the personality, the more often they determine their behavior in accordance with the goals and tasks expressed in law. At the same time, the high level of development of legal consciousness of the personality has an influence on the formation of public legal consciousness in general. That, in turn, promotes the implementation and functioning of real human rights protection mechanisms.

\section{REFERENCES}

1. Васькович Й. Правосвідомість та іiі вплив на менталітет українського народу // Право України. - 1998. - № 6.

2. Вступ до теорії правових систем / НАН України; Інститут держави і права ім. В.М. Корецького / Олег Володимирович Зайчук (заг.ред.), Наталія Миколаївна Оніщенко (заг.ред.). - К. : Юридична думка, 2006.

3. Головченко В., А. Потьомкін Правові механізми формування правосвідомості судентів // Право України, 2006, № 4.

4. Голосніченко I. Правосвідомість і правова культура у розбудові Української держави // Право України, 2005, № 4.

5. Горбунова Л.М., Оніщенко Н.М., Копієвська О.Р. Методика правової освіти. - К.: Атака -Н, 2005. 
6. Державотворення i право творення в Україні: досвід, проблеми, перспективи / За ред. Ю.С. Шемшученка: Монографія. К.: Ін-т держави і права ім.. В.М. Корецького, 2001.

7. Загальна теорія держави і права: Навчальний посібник / МОУ. НПУ ім. М.П. Драгоманова. А.М. Колодій, В.В. Копейчиков та інші. - Стереотипне видання. - Київ: Юрінком Інтер, 1999.

8. Ильин И.А. О сущности правосознания // Теория государства и права. Под. ред. д.ю.н., проф. В.А. Томсинова. - М.: Издательство «Зерцало», 2003.

9. Имбре Само.Основы теории права. Перевод с венгерского под.ред. В.А.Туманова. М., 1974,

10. Каминская В.И, Ратинов А.Р. Правосознание как элемент правовой культуры // Правовая культура и вопросы правового воспитания. М., 1974.

11. Козюбра M.I. Творчий доробок М. Драгоманова. // Драгомаівський збірник. «Вільна спілка» та сучасний український конституціоналізм. За ред. Т.Г. Андрусика. Львів, 1996.

12. Лисенков С.Л. Загальна теорія держави і права. Навчальний посібник. - К.: «Юрисконсульт», 2006.

13. Матузов Н.И. Правовой нигилизм и правовой идеализм, как две сторониы «одной медали» // Правоведение. 1994, № 2.

14. Методологические проблемы правосознания сотрудников внутренних дел. Л., 1986.

15. Новгородцев П.И. Введение в философию права. Кризиссовременного правосознания. - М., 1909.

16. ОніщенкоН.М. Правова система: проблеми теорії: Монографія. - К.: Ін-т держави і права ім. В.М. Корецького НАН України, 2002.

17. Покровский И.Ф. Формирование правосознания личности. Л., 1972.

18. Правові системи сучасності. Глобалізація. Демократизм. Розвиток / В.С. Журавський, О.В. Зайчук, О.Л. Копиленко, Н.М. Оніщенко; За заг. ред. В.С. Журавського. - К.: Хрінком Інтер, 2003.

19. Правовое воспитание молодежи / Н.И. Козюбра, В.В. Оксамытный, П.М. Рабинович и др. Отв. ред. Н.И. Козюбра. - К.: Наукова думка, 1985. 
20. Селиванов В., Діденко Н. Правова природа регулювання суспільних відносин // Право України. - 2000. - № 10.

21. Скакун О.Ф. Теорія держави і права. - К.: Алерта, 2013.

22. Социальные отклонения. Введение в общую теорию. - М.: Юрид. лит., 1984.

23. Соціологія права: Підручник для студентів юрид. Спец. Вищих навчальних закладів / За ред. Н.П. Осипової. - К.: Концерн «Видавничий дім «Ін Юре», 2003

24. Спиридонов Л.И. Теория государства и права. М.,2001.

25. Теорія держави і права. Академічний курс: Підручник для студентів юридичних спеціальностей вищих навчальних закладів / МОНУ; За ред. О.В.Зайчука, Н.М. Оніщенко; Авт.: Зайчук О.В., Засць А.П., Копиленко О.Л., Оніщенко Н.М. та ін. - Київ: Юрінком Інтер, 2008.

26. Хропанюк В.Н. Теорія государства и права. М., 1993.

27. Юридична енциклопедія: В 6 т./ Редкол.: Ю.С. Шемшученко (голова редкол.) та ін. - К.: «Укр. енцикл.», 2001. - Т. 2.

\section{Information about the author: Shvachka V. Yu. Candidate of Judicial Sciences, Assistant Professor}

